\title{
SYNTHESIS AND CHARACTERIZATION OF GOLD NANOPARTICLES USING BELUNTAS LEAFEXTRACT Plucheaindica
}

\author{
Dewi Lidiawati $^{1 *}$, Wahid Wahab ${ }^{1}$, Abd. Karim ${ }^{1}$ \\ ${ }^{1}$ Chemistry Departement, Faculty of Mathematics and Natural Sciences, Hasanuddin University, Perintis \\ Kemerdekaan Street KM. 10 Tamalanrea, Makassar, Indonesia 90245 \\ *Corresponding author: dewilidia13@gmail.com
}

\begin{abstract}
Abstrak. Nanopartikel emas telah berhasil disintesis menggunakan ekstrak daun beluntas sebagai agen pereduksi. Hal ini ditandai dengan terjadinya perubahan warna dari larutan emas berwarna kuning menjadi ungu setelah penambahan ekstrak daun beluntas. Nanopartikel emas yang terbentuk diamati kestabilannya selama 92 jam menggunakan uv-vis dan diperoleh kestabilannya setelah pengukuran 72 jam dengan panjang gelombang sekitar 545.50-546.00 nm. Distribusi ukuran nanopartikel emas ditentukan menggunakan Particle Size Analyzer (PSA) dengan distribusi rata-rata ukuran 101,6 $\mathrm{nm}$. Berdasarkan karakterisasi dengan menggunakan XRD diperoleh pola difraksi pada $2 \theta$ yaitu 38,$1077 ; 44,2935 ; 64,5155 ; 77,4862$ yang menunjukkan keberadaan nanopartikel emas. Selanjutnya dikarakterisasi menggunakan SEM EDX diketahui bentuk rata-rata nanopartikel emas yaitu bola dengan komposisi Au 48\%, C 43,33\%, dan beberapa unsur lain sekitar $8,67 \%$.
\end{abstract}

Kata Kunci : Nanopartikel emas, Sintesis, Daun beluntas, Spektroskopi UV-Vis

\begin{abstract}
Gold nanoparticles have been successfully synthesized using beluntas leaf extract as reducing agents. This is indicated by the change of the color from yellow gold to purplesolution after the addition of the beluntas leaf extract. The gold nanoparticles formed were observed for 92 hours using uv-vis and obtained stability after 72 hours with a wavelength about 545.50-546.00 $\mathrm{nm}$. The size distribution of gold nanoparticles was determined using Particle Size Analyzer (PSA) with an average distribution of $101.6 \mathrm{~nm}$. Based on the characterization using XRD, the diffraction pattern obtained at $2 \theta$ is $38.1077 ; 44,2935 ; 64,5155 ; 77,4862$ which show the presence of gold nanoparticles. Furthermore, it was characterized using SEM EDX showed that the average shape of gold nanoparticles was spherical with a composition of Au 48\%, C 43.33\%, and several other elements around $8.67 \%$.
\end{abstract}

Keywords: Gold Nanoparticles, Synthesis, Beluntas Leaf, UV-Vis Spectroscopy 


\section{INTRODUCTION}

Metal nanoparticles have been extensively studied from several decades ago, the unique properties possessed by nanoparticles make metal nanoparticles more popular in various fields. One of the most widely used metals in making nanoparticles is gold. Gold nanoparticles are the most stable metal nanoparticles, and have attractive properties such as electronic, magnetic and optical properties related to their size, biocompatible, non-cytotoxic properties. Various applications of gold nanoparticles include electronic, photodynamic, sensor, diagnostic and catalyst.

In general, the synthesis of nanoparticles can be done by top-down physics method where nanoparticles are made mechanically, while the bottom-up method uses reducing agents and stabilizers to change metals in nanoparticle sizes (Khairurrijal and Mikrajuddin, 2009) both of which have deficiencies including nonenvironmentally, friendly and requires enormous energy. Biologically nanoparticle synthesis can be done using microorganisms and plants. This method is a safe, cost-effective and environmentally friendly way.

Various types of plants can be used as bioreductors, these plants contain chemical compounds that can act as reducing agents, such as terpenoids and flavanoid secondary metabolites (Purnomo et al. 2017). Such as Pluchea indica Less plants or better known as beluntas. Beluntas contain alkaloids, flavonoids (especially quercetin), tannins, essential oils, chlorogenic acid, sodium, potassium, aluminum, calcium, magnesium, and phosphorus (Desmiaty, et al., 2015). Quercetin is the largest compound of the flavonoid group. The literature search showed that quercetin was able to reduce $\mathrm{Au}^{3+}$ metal to $\mathrm{Au}^{0}$.

\section{MATERIAL AND METHOD Instruments}

The instrument used include analytical scales, UV-Vis Spectrophotometer Shimadzu UV-2600, X-Ray Diffraction (XRD) Zhimadzu 7000, Scanning Electron Microscopy (SEM) EDX JED-2300 JEOL, Particle Size Analyzer (PSA) Vasco, Magnetic Stirrer, drop pipette, volumetric pipette, erlenmeyer, beaker, measuring flask, stirring bar, spray bottle.

\section{Materials}

Some of the materials used are beluntas leaf, aquades, aquabides, Whatmann paper no. 41, $\mathrm{HCl} 16 \mathrm{~N}$, $\mathrm{HNO}_{3} 12 \mathrm{~N}$, gold metal.

\section{Methods}

\section{Preparation of beluntas leaf extract}

Beluntas leaf picked then washed throughly with aquadest. After that, the leafis cut into pieces and weighed 10 grams, then boiled with $50 \mathrm{~mL}$ of aquabides in $100 \mathrm{~mL}$ Erlenmeyer. Next, the stew was left to boil for 5 minutes. After reaching room temperature, boiled water is poured and filtered using Whatman No.1 paper. The water is then be used directly for the biosynthesis process. The water is stored in the refrigerator when it is not in use. 


\section{Preparation of $\mathrm{HAuCl}_{4}$ gold solution 1000 ppm}

Gold metal as much as 1 gram dissolved with $8 \mathrm{~mL}$ of mearegia while heated. The heating is done until gold is completely dissolved and nitric gas, and hydrogen gas has been produced. After the remaining water and $\mathrm{HAuCl}_{4}$ heating solution was stopped and the $\mathrm{HAuCl}_{4}$ solution was diluted in a $1000 \mathrm{~mL}$ measuring flask with aquabides.

$(8 \mathrm{~mL}$ of aquaregia was prepared by mixing $6 \mathrm{ml}$ of $\mathrm{HCl} 16 \mathrm{~N}$ with $2 \mathrm{~mL}$ of $\mathrm{HNO}_{3} 12 \mathrm{~N}$ ).

\section{Biosynthesis of Gold Nanoparticles}

Biosynthesis of gold nanoparticles made by mixing a solution of $\mathrm{HAuCl}_{4}$ and beluntas leaf extract. $1 \mathrm{~mL}$ of beluntas leaf extract as mixed into a 30 $\mathrm{mL} \mathrm{HAuCl}_{4} 1 \mathrm{mM}$ solution, then stirred for 2 hours. The formation of the gold nanoparticles marked by changing solution from yellow to red wine.

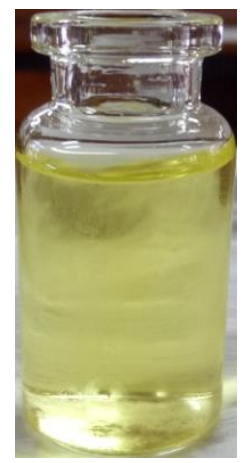

a

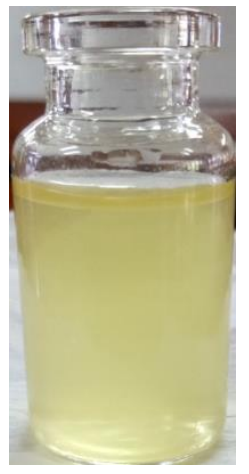

b

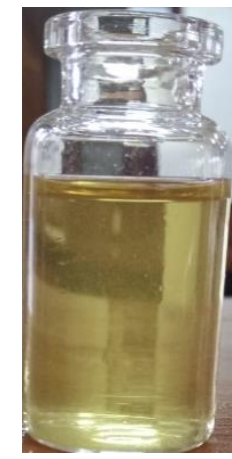

c

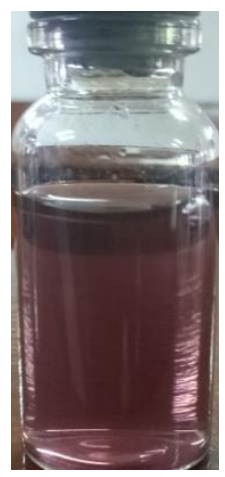

d

Figure 1. (a) $\mathrm{HAuCl}_{4} 1 \mathrm{ppm}$ solution, (b)beluntas leaf extract, (c) $\mathrm{HAuCl}_{4}$ solution + beluntas leaf extract, (d) gold nanoparticles 


\section{Characterization by UV-Vis Spectroscopy}

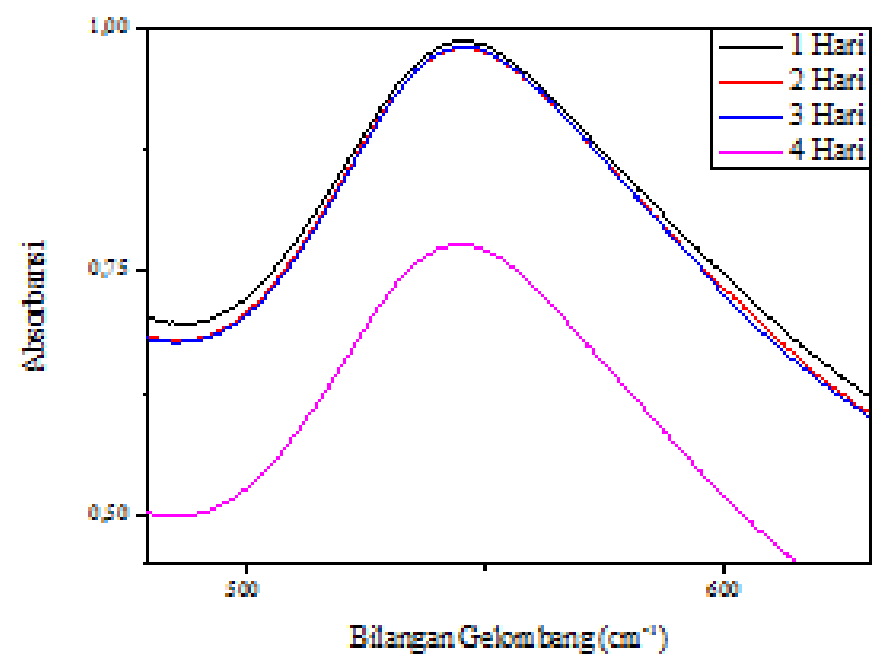

Figure 2. The spectrum of Gold Nanoparticle

Table 1. Wavelength and absorbance at various times

\begin{tabular}{ccccc}
\hline & \multicolumn{4}{c}{ time (hours) } \\
\hline & 24 & 48 & 72 & 96 \\
\hline Wavelength(nm) & 545.50 & 546.00 & 546.00 & 544.50 \\
\hline Absorbance & 0.988 & 0.980 & 0.982 & 0.779 \\
\hline
\end{tabular}

The results of the absorbance of gold nanoparticles using UV-Vis were determined that the gold nanoparticles produced were stable for 72 hours at a wavelength of 545.50-546.00, but at 96 hours there was a decrease in absorbance indicating a larger cluster due to the start of aggregation. Aggregation occurs because the amalgamation of fellow gold nanoparticles forms a larger size.

\section{Characterization by Particle Size Analyzer (PSA)}

Characterization of gold nanoparticles to determine the average diameter size of gold nanoparticles using Particle Size Analyzer (PSA). The results of characterization using PSA obtained intensity dispersions of $161 \mathrm{~nm}$, volume dispersion of $3.7 \mathrm{~nm}$, and number dispersion of $1.7 \mathrm{~nm}$ so that the average nanoparticle size distribution obtained was $101.6 \mathrm{~nm}$.

The results of characterization using PSA are also known as a whole the average diameter size of gold nanoparticles that have been synthesized with a size distribution between $1.4 \mathrm{~nm}$ $1010.7 \mathrm{~nm}$, the highest size distribution is obtained at the size of $1 \mathrm{~nm}-20 \mathrm{~nm}$. 


\section{Characterization with X-Ray Diffraction (XRD)}

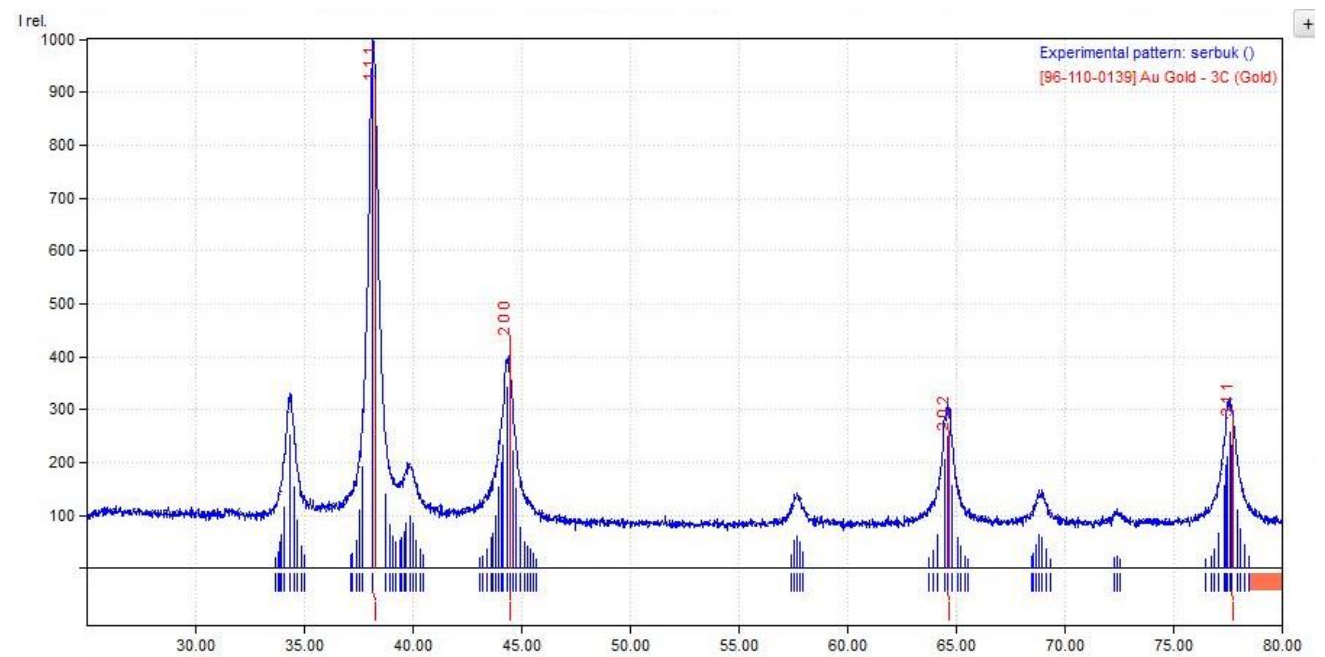

Figure 3. Diffractogram of gold nanoparticles

Figure 3 shows the peaks of the gold nanoparticle diffraction pattern, with Miller Index $\{111\},\{200\},\{202\}$, $\{311\}$, at a value of $2 \theta, 38,1077$; 44,2935; 64,5155; 77,4862. The appearance of the diffraction pattern besides the diffraction of gold nanoparticles shows that the nanoparticles produced are not completely pure.

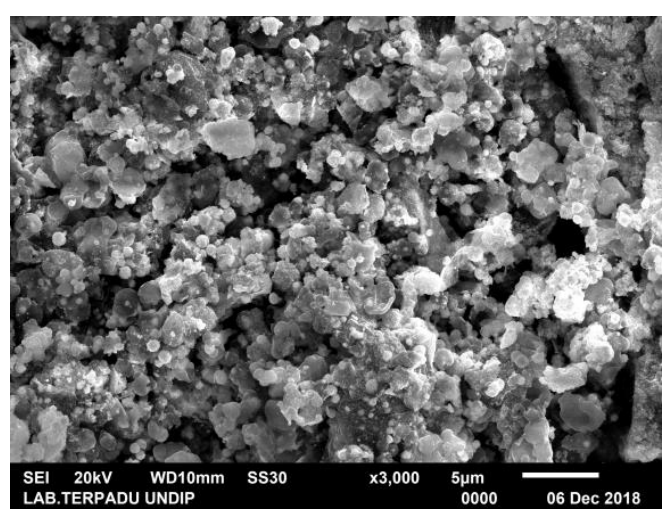

a

\section{Characterization Scanning Electron Microscopy (SEM) EDX}

The characterization of Scanning Electron Microscopy (SEM) aims to determine the morphological shape of the surface layer. The results of the SEM analysis with a magnification of 3.00040.000 times showed that gold nanoparticles have a dominant structure with a spherical shape.

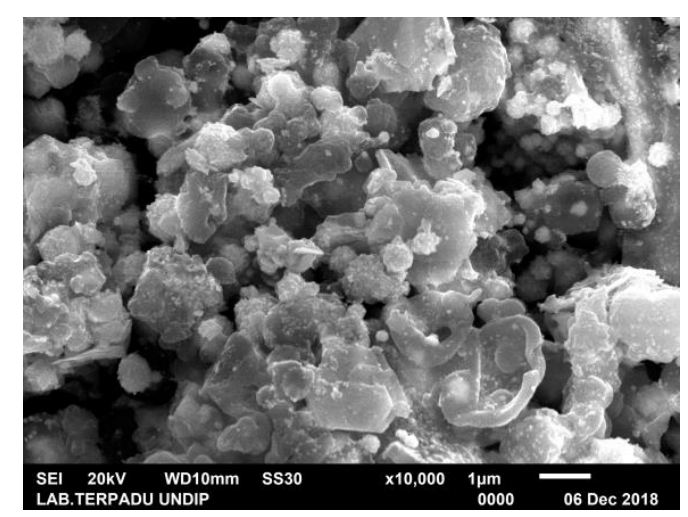

b 


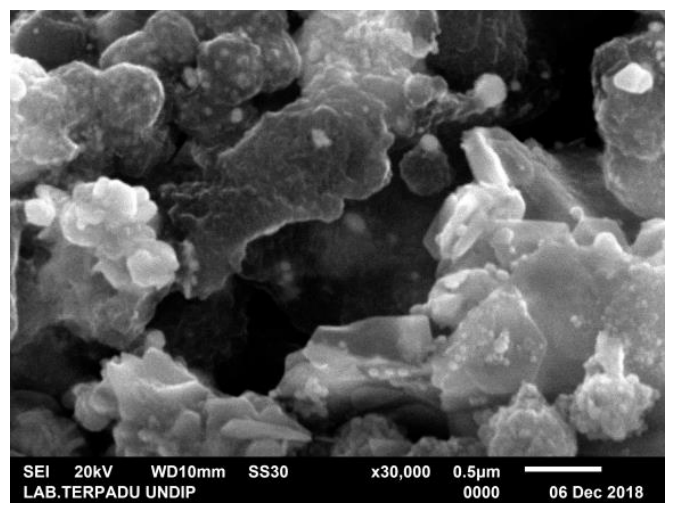

c

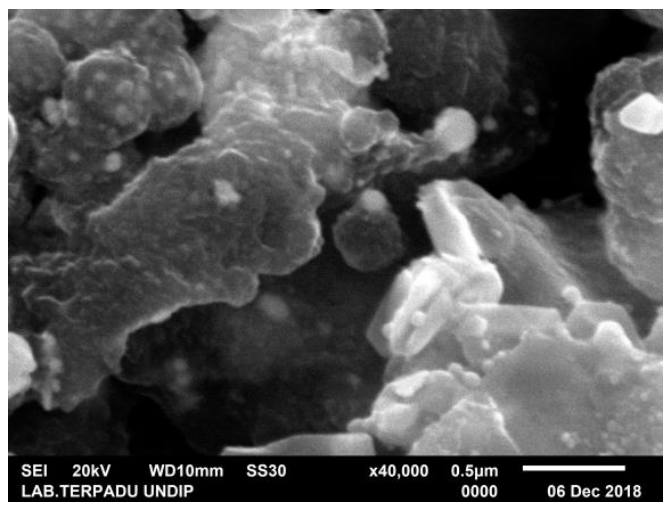

d

Figure 4. Photograph of Scanning Electron Microscopy (SEM), (a) 3000x magnification, (b) $10,000 \mathrm{x}$ magnification, (c) 30,000x magnification, (d) 40,000x magnification

The analysis using EDX shows that the composition of the gold nanoparticles produced consisted of several types including Gold $(\mathrm{Au})$ of $48 \%$, Carbon $43.33 \%$, about $8.67 \%$ of other elements such as $\mathrm{Na}_{2} \mathrm{O}, \mathrm{Al}_{2} \mathrm{O}_{3}$, $\mathrm{SO}_{3}, \mathrm{Cl}, \mathrm{K}_{2} \mathrm{O}, \mathrm{CaO}$, some Other elements or compounds are thought to originate from beluntas extract and aquabides which are used to dissolve gold into $\mathrm{HAuCl}_{4}$.

\section{CONCLUSION}

The research that has been done can be concluded that it has been synthesized gold nanoparticles using beluntas leaf extract. The gold is measured after 72 hours of measurement with a wavelength of about 545.50 $546.00 \mathrm{~nm}$. The average size of gold nanoparticles characterized using PSA obtained a value of $101.6 \mathrm{~nm}$. XRD characterization results show the peaks of the gold nanoparticle diffraction pattern, with Miller Index $\{111\},\{200\}$, $\{202\},\{311\}$, at the value of $2 \theta$, 38,$1077 ; 44,2935 ; 64,5155 ; 77,4862$.
Characterization of SEM EDX with a magnification of 3000x - 40,000x shows that gold nanoparticles have a surface structure with the dominant shape of the ball with a composition of $\mathrm{Au} 48 \%, \mathrm{C}$ $43.33 \%$ and $8.67 \%$ other compounds.

\section{REFERENCES}

Desmiaty, Y., Puspitasari, A., Zuhri, U.M. 2015. Test of Xanthine Oxidase Inhibition and Determination of Quercetin Levels Guava Leaf Extract (Psidium Guajava L.) and Beluntas Leaves (Pluchea Indica Less.). University of General Achmad Yani.

Jingyue, Z., Bernd, F. 2015. Synthesis Of Gold Nanoparticles Via Chemical Reduction Methods. Nanocon.

Khairurrijal and Mikrajuddin. 2009. Building the Ability of Nanomaterial Research in Indonesia. Bandung Institute of Technology (ITB).

Purnomo, S., R., Rupiasih, N., N., Sumadiyasa, M. 2017. Study of Synthesis of Silver Nanoparticles 
by Biological Methods Using Sambiloto Plants (Andrographis Paniculata Ness). Physics Bulletin 18: 1 .

Singh, C., Baboota, R.K., Naik, P.K., Singh, H. 2012.Biocompatible synthesis Of Silver And Gold Nanoparticles Using Leaf Extract of Dalbergia sissoo.Adv. Mat. Lett 3(4): 279-285

Yasser M., Widiyanti S. E., Arif A. R. 2017. Synthesis And Characterization of Gold Nanoparticles Using Teakleaf Extract Tectona Grandis. Indonesia Chimica Acta 10:1. 